\title{
Impact of glyphosate formulations and adjuvants: effects on leaf interaction, metabolism, and control of sourgrass
}

\author{
Jhonatan Diego Cavalieri ${ }^{*}$ (D) Samuel Alves dos Santos ${ }^{2}$ Caio Antonio Carbonari ${ }^{3}$ (D) \\ Carlos Gilberto Raetano ${ }^{3}$ (D)
}

1Departamento de Ciências Agronômicas, Universidade Federal do Paraná (UFPR), 85950-000, Palotina, PR, Brasil. E-mail: jdcavalieri@gmail.com. ${ }^{*}$ Corresponding author.

${ }^{2}$ Departamento de Fitopatologia, Universidade Federal de Viçosa (UFV), Viçosa, MG, Brasil.

${ }^{3}$ Departamento de Proteção Vegetal, Faculdade de Ciências Agronômicas, Universidade Estadual Paulista “Júlio de Mesquita Filho" (FCA/UNESP), Botucatu, SP, Brasil.

\begin{abstract}
The addition of commercial formulations and adjuvants to a tank mix may result in differences in the wettability on the plant surface, foliar uptake and herbicide efficacy. Thus, the objectives of this study were to evaluate the influence of glyphosate formulations and tankmixture adjuvants on the contact angle (CA), uptake, metabolism and sourgrass control and the damage to the cuticular microstructure of this species caused by herbicide solutions. For this purpose, assays were carried out in a completely randomized design, and treatments distributed in a 2x5+1 factorial scheme with five replications. Two glyphosate formulations isopropylamine salt (SL) and ammonium salt (WG) combined or not with the adjuvant methylated soybean oil (MSO), mineral oil (MO), ethoxylated alkyl ester (EAE) or polyoxyethylenealkylphenol ether (PAE); and one control (water) were evaluated. CA measurements of the droplets deposited on a sourgrass leaf surface and on the standard surface (parafilm) were obtained using a tensiometer. Herbicide uptake and shikimate accumulation were simultaneously determined by chromatography and spectrometry. The control effect was assessed by observing plant survival dry weight reductions. The glyphosate SL and WG formulations had similar effects on the variables analyzed. However, mixing the adjuvants EAE, MO or MSO with either formulation of herbicide led to greater wettability and more severe damage to the cuticular microstructure, favoring glyphosate uptake and shikimate accumulation. Despite evidence regarding the treatments containing oils/surfactants, the control effect on sourgrass was similar. The combination of glyphosate formulations with such adjuvants is potentially more effective and guarantees satisfactory sourgrass control.
\end{abstract} Key words: Digitaria insularis (L.) Fedde, herbicide, contact angle, scanning electron microscopy, shikimic acid.

Impacto das formulações de glifosato e dos adjuvantes: efeitos na interação foliar, no metabolismo e no controle do capim-amargoso

RESUMO: Formulações comerciais e adjuvantes adicionados à mistura em tanque podem resultar em mudanças na superficie de molhamento, absorção foliar e eficácia dos herbicidas. Assim, objetivou-se com este trabalho avaliar a influência das formulações de glifosato e adjuvantes sobre o ângulo de contato (CA), absorção, metabolismo e controle do capim-amargoso, além de investigar os danos ocasionados pelas soluções herbicidas à microestrutura cuticular dessa espécie daninha. Para tanto, ensaios foram conduzidos em delineamento inteiramente casualizado, e os tratamentos distribuidos em esquema fatorial $2 x 5+1$, com cinco repetições. Duas formulações de glifosato (SL e WG) combinadas ou não com os adjuvantes éster metílico de óleo de soja (MSO), óleo mineral (MO), alquil ester etoxilado (EAE) e polioxietilenoalquilfenoléter (PAE); e um controle (água) foram avaliados. As medidas de CA das gotas depositadas na superficie foliar de capim-amargoso e na superficie padrão (parafilme) foram obtidas usando um tensiômetro. A absorção do herbicida e o acúmulo de chiquimato foram determinados, simultaneamente, por cromatografia e espectrometria de massas. O efeito de controle foi avaliado pela observação da sobrevivência da planta e redução do peso seco. As formulações de glifosato SL e WG apresentaram efeitos similares sobre as variáveis analisadas. Contudo, os adjuvantes EAE, MO e MSO, quando em mistura ao herbicida, em ambas as formulações, destacaram-se por apresentar maior molhabilidade e danos mais severos à microestrutura cuticular, favorecendo a absorção do glifosato e acúmulo de chiquimato. Apesar das evidências sobre a bioeficácia dos tratamentos que continham óleos/surfactantes, o controle sobre capim-amargoso foi similar. A combinação das formulações de glifosato com tais adjuvantes são potencialmente mais eficazes e garantem controle satisfatório do capim-amargoso.

Palavras-chave: Digitaria insularis (L.) Fedde, herbicida, ângulo de contato, microscopia eletrônica de varredura, ácido chiquímico.

\section{INTRODUCTION}

Digitaria insularis (L.) Fedde is commonly known as sourgrass, a perennial grass and rhizomatous weed with tillered growth. This species naturally occurs in a wide variety of environments, including fields with annual or perennial crop cultivations, pastures, vegetable gardens and ruderal areas such as roads and vacant lots (SILVEIRA et al., 2018). Its development is interspersed between initial slow

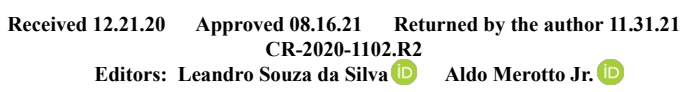


growth and subsequent exponential gains in biomass, which renders it highly competitive in capturing environmental resources (GEMELLI et al., 2012).

Glyphosate (N-phosphonomethyl glycine) is a systemic and non selective postemergence herbicide. Despite resistance development in recent years (LOPES OVEJERO et al., 2017; SILVEIRA et al., 2018), it is considered one of the main chemical tools for sourgrass control due to its high effectiveness and versatility of use over different growth stages of plants. It acts by inhibiting 5-enolpyruvylshikimate-3-phosphate (EPSPS) synthase, leading to interruption of aromatic amino acid (tryptophan, tyrosine and phenylalanine) biosynthesis and shikimic acid accumulation in sensitive plants (DUKE \& POWLES, 2008).

The extraction and quantification of compounds related to the shikimate pathway are extremely important for the detecting plant injury due to glyphosate (GOMES et al., 2015). The efficiency of sprayed solutions has been evaluated based on quantification of absorbed glyphosate and accumulated shikimate in tissues, serving as references for treatments performance (SCHRÜBBERS et al., 2014).

Different herbicide formulations applied in the form of foliar spraying, as well as adjuvants added to spray solution, can influence the steps of foliar application of agrochemicals, including the formation of droplets at their final destination (spectrum, speed, drift, evaporation, and deposition), when they intersect the target (adhesion, retention, bounce and sliding), when they are in contact with the leaf surface (wettability, spreading and humectant), and the dynamics of additive movement in the target (persistence, uptake and translocation) (ARAND et al., 2018; NAIRN et al., 2015).

In Brazil, many glyphosate formulations are commercially available, which differ in salt composition, active ingredient (AI) concentrations, and physicochemical nature. In addition, additives/ adjuvants are incorporated into formulations as inert ingredients (in-can adjuvants), fulfilling functions related to the stability of the formulations, the compatibility of the mix, and bio performance improvement (BAUR \& APONTE et al., 2014).

The adjuvants added to the tank mix (tankmixture adjuvants) perform basic functions similar to those present in the formulations; however, for economic reasons or due to mix compatibility, they are added after the manufacturing process. The most commonly used tank-mixture adjuvants include vegetable oil and mineral oil (MO), emulsified oils, nonionic surfactants and polymers (APPAH et al., 2020). In general, oil-based adjuvants, such as vegetable oil or mineral oil, increase IA penetration and, influence transport properties across the cuticle (MELO et al., 2015). Among the adjuvants, surfactants have a more pronounced effect on surface tension, which may result in a greater spreading area of the liquid, and retention of the liquid, and can lead to greater absorption and treatment efficacy (PALMABAUTISTA et al., 2020).

Glyphosate is a high-solubility herbicide with a $\log \mathrm{Ko} / \mathrm{w}$ between -2.77 and -3.22 (RODRIGUES \& ALMEIDA, 2018). When applied alone, does not easily diffuse through waxy cuticles. However, the use of additives together with the AI facilitates its penetration and improves its efficacy. Surfactants with low ethylene oxide (EO) content are known to readily penetration through the cuticle and facilitate IA uptake through the lipophilic pathways of this membrane (STOCK et al., 1992; SHI et al., 2005). Adjuvants with a high EO content increase the permeability of hydrophilic solutes (LIU, 2004; BAUR \& APONTE 2014), mainly due to their humectant activity (ASMUS et al., 2016).

Most studies to evaluating the effects of herbicide solutions regarding the parameters of the application technology have not considered the interaction between formulations and adjuvants, as well as the importance of cuticle layer micromorphology. Moreover, the limited numbers of variables used in the studies do not allow observation of the individual processes affected by the treatments. Thus, the objective of this study was to evaluate the influence of glyphosate formulations and adjuvants on the contact angle (CA), uptake, metabolism and control of sourgrass.

\section{MATERIALS AND METHODS}

Four assays were performed to evaluate the following: 1, CA; 2, micromorphology; 3, glyphosate uptake and shikimic acid formation; and 4, sourgrass control. The experiments were set up under a completely randomized experimental design, and the treatments were distributed in a $2 \times 5+1$ factorial scheme. Two glyphosate herbicide formulations, isopropyl amine salt (SL, Roundup Original ${ }^{\circledR}$, Monsanto Ltda., São Paulo, Brazil) and ammonium salt (Roundup $\mathrm{WG}^{\circledR}$, Monsanto Ltda., São Paulo, Brazil) were combined with or without the following adjuvants: methylated soybean oil (MSO, Aureo ${ }^{\circledR}$, Bayer S.A., São Paulo, Brazil), mineral oil (Nimbus ${ }^{\circledR}$, Syngenta Proteção de Cultivos Ltda., São Paulo, Brazil), ethoxylated alkyl ester (EAE, Lanzar ${ }^{\mathbb{B}}$, Arysta LifeScience Indústria Química e Agropecuária Ltda., 
São Paulo, Brazil) or polyoxyethylenealkylphenol ether (PAE, Iharaguen-s $\mathrm{s}^{\circledR}$, Iharabras S.A. Indústrias Químicas, Sorocaba, Brazil) plus a control treatment (water), totaling 11 treatments (Table 1) and five replications. Glyphosate was added to the spray solution at a dose of $1080 \mathrm{~g}^{\mathrm{ae}} \mathrm{ha}^{-1}$, corresponding to the commercial dose of the herbicide listed in the package insert for the control of sourgrass in Brazil (Roundup $\mathrm{WG}^{\circledR}$, Monsanto Ltda.). The adjuvants were mixed with the herbicide solutions at various concentrations according to their recommendations in the package insert (Table 1).

\section{Origin of the plant species and spraying}

The sourgrass seeds used in the assays were collected from 40 plants present in vacant lots located in the Avaré municipality, São Paulo, Brazil (2350'81'84"; 4882'43.53"). Plants originating from these seeds were subjected to preliminary tests to confirm their sensitivity to glyphosate. The plants were treated at the stage of two to four tillers, and the following parameters were obtained for visual evaluation of weed control: lethal dose for $50 \%$ of plants $\mathrm{LD}_{50}$ ) $=417.80 \mathrm{~g}$ a.e. $\mathrm{ha}^{-1}$ and $\mathrm{LD}_{80}=552.47 \mathrm{~g}$ a.e. $\mathrm{ha}^{-1}$, with the mortality of plants recorded at 21 days after application (DAA). After this preliminary evaluation, the sourgrass was sown in 1-L polyethylene pots filled with approximately $300 \mathrm{~cm}^{3}$ of commercial substrate (Carolina Soil ${ }^{\circledR}$, Carolina Soil do Brasil, Pardinho, São Paulo), with three plants per pot. These plants were grown in a semicontrolled greenhouse at São Paulo State University (School of Agricultural Sciences,
Botucatu, São Paulo, 22 51'04.6”S, 48²5'53.5”W) with a temperature of $22 \pm 5^{\circ} \mathrm{C}$ and a relative humidity of $50 \pm 15 \%$. For application in assays 2,3 , and 4 , a mobile spraying system with flow rate and pressure control was used. The treatments were applied in the laboratory under controlled conditions of temperature $\left(24{ }^{\circ} \mathrm{C}\right)$ and relative humidity $(60 \%)$ when the plants reached 2 to 4 tillers $(0.20$ to $0.40 \mathrm{~m})$. The system was equipped with a 3.0-m-length spray boom and AXI 11003 flatfan spray nozzles (Jacto of Brazil, São Paulo) spaced $0.50 \mathrm{~m}$ apart. The spray equipment was calibrated for application at $200 \mathrm{kPa}$ with a flow rate of $0.83 \mathrm{~L} \mathrm{min.-}$ ${ }^{1}$ and displacement velocity of $5.0 \mathrm{~km} \cdot \mathrm{h}^{-1}$, providing a spray volume equivalent to $200 \mathrm{~L} \mathrm{ha}^{-1}$.

Assays

\section{1 - Contact angle (CA)}

The CA of droplets formed by the different solutions was measured on the natural surfaces of sourgrass and a standard artificial surface (parafilm), and these measurements were used to estimate the wettability of the treatments.

This experiment was carried out at the Particle Size Analysis Laboratory (LAPAR) of São Paulo State University (School of Agriculture and Veterinary Sciences, Jaboticabal, São Paulo). The CA was measured using an automatic tensiometer (Model OCA 15-Plus, Dataphysics, Germany), fitted with a high-resolution and high-definition digital camera, and SCA20 software was used for automation and image processing. The droplets were formed using a high-precision syringe with 5.0 a $\mu \mathrm{L}$

Table 1 - Formulations and adjuvants used in their respective commercial concentrations.

\begin{tabular}{|c|c|c|c|}
\hline Trat. - Formulation & Adjuvant and Acronym & $\left(\mathrm{v} \cdot \mathrm{v}^{-1}\right)$ & Class \\
\hline 1- Test. (Water) & - & - & - \\
\hline 2 - Isoprop. (SL) ${ }^{1}$ & without adjuvant & - & - \\
\hline 3 - Isoprop. (SL) & methylated soybean oil - MSO & $0.1 \%$ & Vegetable oil \\
\hline 4 - Isoprop. (SL) & $\begin{array}{l}\text { mineral oil - MO } \\
\text { Ltda., São Paulo }\end{array}$ & $0.5 \%$ & Mineral oil \\
\hline 5 - Isoprop. (SL) & ethoxylated alkyl ester - EAE & $0.5 \%$ & Surfactant \\
\hline 6 - Isoprop. (SL) & polyoxyethylenealkylphenol ether - PAE & $0.1 \%$ & Spreader sticker \\
\hline 7 - Ammon. $(\mathrm{WG})^{2}$ & without adjuvant & - & - \\
\hline 8 - Ammon. (WG) & methylated soybean oil - MSO & $0.1 \%$ & Vegetable oil \\
\hline 9 - Ammon. (WG) & $\begin{array}{l}\text { mineral oil - MO } \\
\text { Ltda., São Paulo, }\end{array}$ & $0.5 \%$ & Mineral oil \\
\hline 10 - Ammon. (WG) & ethoxylated alkyl ester - EAE & $0.5 \%$ & Surfactant \\
\hline 11 - Ammon. (WG) & polyoxyethylenealkylphenol ether - PAE & $0.1 \%$ & Spreader sticker \\
\hline
\end{tabular}

${ }^{1}$ Isoprop. (SL) - Isopropylamine salt (Roundup Original ${ }^{\circledR}$, Monsanto Ltda., São Paulo, Brazil) in soluble concentrate formulation.

${ }^{2}$ Ammon. (WG) - Ammonium salt (Roundup $W^{\circledR}{ }^{\circledR}$, Monsanto Ltda., São Paulo, Brazil) in a dispersible granulate formulation. 
of volumetric capacity (Hamilton Company, United States) at a droplet release rate of $3.0 \mu \mathrm{L} \mathrm{s}^{-1}$ and were used to measure the CA. For the natural surfaces, the medial portion of the youngest fully expanded and visually healthy leaves was used as a reference for comparison between treatments. Each droplet was deposited between two secondary leaf veins on the adaxial surface of the leaves. This surface served as a reference for the CA due to a tendency for greater accumulation of sprayed solutions (CAVALIERI et al., 2015). The software was programmed to perform one reading per second over a total time of 60 seconds. For treatments comparisons, only the measurements obtained at 5, 30 and 60 seconds after droplet deposition on the surfaces were considered.

CAs are regularly used to characterize the affinity of spray droplets for a surface considering the interaction factors of liquid propagation on the surface and the wetted area as a result of spraying. When the $\mathrm{CA}$ is greater than $90^{\circ}\left(90-150^{\circ}\right)$, the surface is considered hydrophobic; otherwise, it is considered hydrophilic. When the CA exceeds $150^{\circ}$, the surface is superhydrophobic (BARTHLOTT et al., 2017).

\section{2 - Leaf micromorphology changes and stomatal density}

To evaluate the damage caused by the herbicide solutions to the leaf microstructure on the adaxial surface of sourgrass, scanning electron microscopy (SEM) was used. In addition, stomatal density was measured on both leaf surfaces. This experiment was carried out in an electron microscopy laboratory at the Luiz de Queiroz School of Agriculture, Piracicaba, São Paulo state, Brazil. The plants treated in the laboratory were transferred to the greenhouse and left for 48 hours. Then, four leaf pieces measuring approximately $0.5 \mathrm{~cm}^{2}$ were cut with a metal blade. Leaf samples were removed from the plants in different pots. The medial part of the youngest fully expanded and visually healthy leaf was used for sampling. After cutting, the fragments were placed in 2-mL Eppendorf tubes with Karnovsky's fixative solution (KARNOVSKY, 1965). Sample preparation for SEM as well as the other procedures followed the methodology described by COSTA et al. (2020).

\section{3 - Herbicide uptake and shikimic acid (shikimate) formation}

The levels of glyphosate absorbed and shikimic acid accumulated in the superior tissues of the plants after spraying the herbicide solutions were quantified using a Shimadzu Prominence UHPLCMS/MS instrument and a Triple Quad 4500 triple quadrupole hybrid mass spectrometer (AB SCIEX,
United States). After application of the treatments, the plants were left for 24 hours in a greenhouse. Next, the plants were cut immediately above the soil surface and stored in labeled polyethylene bags. The glyphosate present on the plant surface was removed by washing with $300 \mathrm{~mL}$ of distilled water, in three washes with $100 \mathrm{~mL}$ each. The samples were then dried in a forced-air oven at $40{ }^{\circ} \mathrm{C}$ for 5 days until the plant material was completely dry. Then, the plants were stored in a freezer until maceration using liquid nitrogen. The equipment and other procedures used for extraction and quantification of the compounds in the plant tissues followed the methodology developed by GOMES et al. (2015). Glyphosate and shikimic acid levels were determined by the concentration of each compound ( $\mu \mathrm{g} \mathrm{g}^{-1} \mathrm{dw}$ ) found in the upper parts of the plants. The time-point of 24 hours after application (HAA) was selected for uptake and metabolism valuations based on the results presented by CARVALHO et al. (2012). This time corresponds to the peak herbicide uptake in the plant (approximately 80\%) and an intermediate effect of shikimate formation and is sufficient to show the differences between treatments but no so long as to enable translocation of the herbicide to underground plant parts, where the product would not be detected.

\section{4 - Control of sourgrass}

Control assessments were performed by examinating of the visual symptoms at 7,14 , and 21 DAA and the residual dry matter, collected at 21 DAA. A scoring scale was used to assign values ranging from $0 \%$ (no symptoms) to $100 \%$ (plant death) according to the scale proposed by Sociedade Brasileira da Ciência das Plantas Daninhas - SBCPD (1995). The plants were then cut immediately above the soil surface and stored in labeled paper bags. They were then dried in a FANEM forced-air oven, model $320 / 5-\mathrm{MP}(220 \mathrm{~V}$ and $5200 \mathrm{~W})$, at a temperature of $60 \pm 5{ }^{\circ} \mathrm{C}$ until reaching a constant weight. Then, the plants were weighed on a Marte AY220 highprecision balance $(0.001 \mathrm{~g}$; Shimadzu, Barueri, São Paulo, Brazil), and the data were used to calculate the dry matter percentage relative to that in the control.

\section{Statistical analysis.}

Initially, the data were tested using Levene's test $(\mathrm{P}>0.05)$ and the Shapiro Wilk $(\mathrm{P}$ $>0.05)$ tests to assess the homoscedasticity and normality of errors. Subsequently, analysis of variance was conducted, and the F test was applied. When significant differences were found, the means of the treatments were compared with that of the absolute 
control by Dunnett's test, while pairwise comparisons among the means of the treatments were performed by Tukey's test, both at $5 \%$ probability $(\mathrm{P}<0.05)$. Tests were also performed to evaluate correlations (Pearson, $\mathrm{P}<0.05$ ) between the wettability, uptake, and metabolism variables.

\section{RESULTS AND DISCUSSION}

\section{Contact angle (CA)}

In general, the $\mathrm{F}$ values of the analysis of variance (ANOVA) revealed differences ( $\mathrm{P}<$ 0.05 ) between the formulations and adjuvants and interactions between the factors on the artificial surface - Parafilm (Table 2). However, on the natural surface (sourgrass), differences were observed only between the adjuvants (Table 2). The magnitude of the $\mathrm{F}$ values for the adjuvant factor on the two examined surfaces indicates that this factor has a greater impact on the $\mathrm{CA}$ than the formulations factor, demonstrating advantages in addition to the adjuvants in both glyphosate formulations to optimize the wetting and spreading of the liquid on the surfaces of weeds.
The CA of pure water on a parafilm surface was approximately $100^{\circ}$, which can be classified as hydrophobic (BARTHLOTT et al., 2017). On the adaxial surface of sourgrass leaves, the water CA values were approximately $152^{\circ}$, allowing classification as a superhydrophobic surface and thus reflecting a very difficult-to-wet surface (BARTHLOTT et al., 2017). The CA values of sourgrass with water were higher than those of other grasses, such as wheat and corn, which have CAs of 120 and $112^{\circ}$, respectively (MELO et al., 2015), and much higher than those obtained for some fabaceous species, which have CAs of $70-107^{\circ}$ (SANTOS et al., 2019), demonstrating the strong water repellency of the sourgrass foliar surface. In this case drops remain spherical shape on top of the wax crystalloids after deposition $(\mathrm{KOCH}$ et al., 2009), resulting in minimal contact between the drops and the leaf surface. Characteristics such as droplet adherence and retention are difficult to optimize, especially in this species due to its vertical growth architecture (MASSINON et al., 2017), increasing the possibility of AI losses due to runoff droplets.

The addition of the glyphosate formulations to water was sufficient to reduce the CA

Table 2 - Contact angle (CA) of water (control) and glyphosate solutions on artificial (parafilm) and natural (sourgrass) surfaces, three times after the droplet deposition.

\begin{tabular}{|c|c|c|c|c|c|c|}
\hline \multirow[t]{3}{*}{ Adjuvants } & \multicolumn{6}{|c|}{ 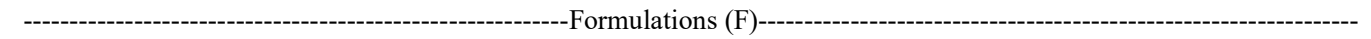 } \\
\hline & \multicolumn{2}{|c|}{--------------------5 s------------------------- } & \multicolumn{2}{|c|}{----------------------30 s-------------------- } & \multicolumn{2}{|c|}{-------------------60 s----------------- } \\
\hline & SL & WG & SL & WG & SL & WG \\
\hline Without adj. & $83.3 \mathrm{aA}$ & $80.7 \mathrm{bA}$ & $81.0 \mathrm{aA}$ & $77.0 \mathrm{bA}$ & $80.0 \mathrm{aA}$ & $74.8 \mathrm{bA}$ \\
\hline PAE & $73.5 \mathrm{bB}$ & $80.6 \mathrm{aA}$ & $69.2 \mathrm{bB}$ & $75.1 \mathrm{aA}$ & $66.7 \mathrm{bB}$ & $72.5 \mathrm{aA}$ \\
\hline MSO & $75.1 \mathrm{aB}$ & $73.7 \mathrm{aB}$ & $69.2 \mathrm{aB}$ & $65.5 \mathrm{bB}$ & $66.5 \mathrm{aB}$ & $62.4 \mathrm{bB}$ \\
\hline MO & $73.1 \mathrm{aB}$ & $70.4 \mathrm{bB}$ & $66.8 \mathrm{aBC}$ & $61.4 \mathrm{bC}$ & $61.5 \mathrm{aC}$ & $55.8 \mathrm{bC}$ \\
\hline EAE & $74.6 \mathrm{aB}$ & $72.4 \mathrm{aB}$ & $64.6 \mathrm{aC}$ & $63.1 \mathrm{aBC}$ & $61.3 \mathrm{aC}$ & $58.8 \mathrm{aBC}$ \\
\hline Water & \multicolumn{2}{|c|}{ 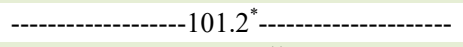 } & \multicolumn{2}{|c|}{----------------------'98.5* } & \multicolumn{2}{|c|}{-------------------'97.4*'------------------ } \\
\hline $\mathrm{F}_{(\mathrm{F})} ; \mathrm{F}_{(\mathrm{A})}$ & \multicolumn{2}{|c|}{ - $0.5^{\text {ns }} ; 48.2^{* *}$} & \multicolumn{2}{|c|}{--------------8.9** $; 95.5^{* *}--------------$} & \multicolumn{2}{|c|}{--1 $11.5^{* *} ; 99.4^{* *}-$} \\
\hline \multirow{2}{*}{$\mathrm{F}_{(\mathrm{FxA})} ; \mathrm{CV}$} & \multicolumn{2}{|c|}{--------------13.4** $; 2.1 \%$------------------- } & \multicolumn{2}{|c|}{---------------11.8** $; 2.6 \%$----------------- } & \multicolumn{2}{|c|}{-------------9.3** $; 3.2 \%$----------------- } \\
\hline & \multicolumn{6}{|c|}{ 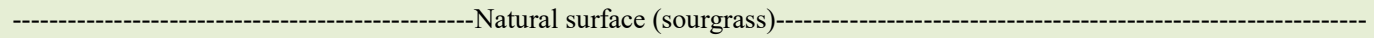 } \\
\hline Without adj. & $134.1 \mathrm{aA}^{1}$ & $137.0 \mathrm{aA}$ & $132.6 \mathrm{aA}$ & $136.1 \mathrm{aA}$ & $132.7 \mathrm{aA}$ & $133.1 \mathrm{aA}$ \\
\hline PAE & $132.9 \mathrm{aA}$ & $131.7 \mathrm{aAB}$ & $132.6 \mathrm{aA}$ & $130.4 \mathrm{aA}$ & $129.8 \mathrm{aA}$ & $128.8 \mathrm{aA}$ \\
\hline MSO & $129.3 \mathrm{aA}$ & $126.9 \mathrm{aBC}$ & $122.6 \mathrm{aB}$ & $117.9 \mathrm{aB}$ & $118.3 \mathrm{aB}$ & $111.2 \mathrm{bB}$ \\
\hline MO & $122.1 \mathrm{aB}$ & $126.6 \mathrm{aBC}$ & $114.2 \mathrm{aC}$ & $114.5 \mathrm{aBC}$ & $108.9 \mathrm{aC}$ & $109.3 \mathrm{aB}$ \\
\hline EAE & $122.1 \mathrm{aB}$ & $120.8 \mathrm{aC}$ & $106.4 \mathrm{aD}$ & $108.6 \mathrm{aC}$ & $97.3 \mathrm{bD}$ & $102.3 \mathrm{aC}$ \\
\hline Water & \multicolumn{2}{|c|}{-------------------154,7*------------------------ } & \multicolumn{2}{|c|}{------------------'152.02*-------------------- } & \multicolumn{2}{|c|}{-------------------151.3'----------------- } \\
\hline $\mathrm{F}_{(\mathrm{F})} ; \mathrm{F}_{(\mathrm{A})}$ & \multicolumn{2}{|c|}{-----------0.20 $0^{\text {ns. }} ; 21.33^{* *}$} & \multicolumn{2}{|c|}{------------0.03 ${ }^{\text {ns}} ; 88.51^{* *}$} & \multicolumn{2}{|c|}{-----------0.3 ${ }^{\text {ns. }} ; 203.4^{* *}-----------$} \\
\hline $\mathrm{F}_{(\mathrm{FxA})} ; \mathrm{CV}$ & \multicolumn{2}{|c|}{ 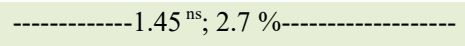 } & \multicolumn{2}{|c|}{ 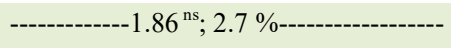 } & \multicolumn{2}{|c|}{ 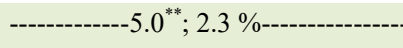 } \\
\hline
\end{tabular}

${ }^{n s}$ Not significant $(\mathrm{P}>0.05) ;{ }^{* *}$ Significant $(\mathrm{P}<0.05)$ by the $\mathrm{F}$ test; Averages followed by the same letter, lowercase on the line and uppercase on the column for each time, do not differ by Tukey's test $(\mathrm{P}<0.05)$; ${ }^{*}$ Indicates a difference in the control (water) compared to other treatments, by Dunnett's test $(\mathrm{P}<0.05)$ 
by approximately $20^{\circ}$, on both parafilm and sourgrass surfaces, suggesting the presence of surfactants and other components within the formulations with an effect on wettability. A slight difference was observed when comparing isolated herbicidal formulations (without adjuvants) on parafilm surfaces, with the results favoring the WG formulation. On natural surfaces, in general, no differences were observed between formulations (Table 2).

When adjuvants were added to the herbicide solution, the CA was reduced by approximately $40^{\circ}$ on parafilm and $54^{\circ}$ on the sourgrass surface compared to that with water. In the comparison between adjuvants, major CA reductions were achieved with the treatments containing the nonionic surfactants $\mathrm{EAE}$ and $\mathrm{MO}$, in compared to treatments without adjuvants on both the natural and artificial surfaces. EAE was more efficiently in reduced the CA than MO, especially with prolonged contact time on the sourgrass surface. As the droplets deposited on the target dried, the relative adjuvant concentration increased, and the difference between treatments became more evident, which may result in a large difference in the spread area (ARAND et al., 2018).

The reduction in the $\mathrm{CA}$ values of the mixtures can be attributed to the effect of liquid surface tension (surface molecular forces) due to the presence of surfactants. Moreover, the polarity of the spray solution and its strong correlation with the chemical nature of the leaf surface of sourgrass (NAIRN et al., 2015) can explain the differences obtained between treatments.

The above data indicate that the moderate reduction in surface tension and the consequent increase in wettability can benefit absorption, especially on superhydrophobic surfaces, due to greater adhesion and retention of the sprayed liquid (ARAND et al., 2018), which results in a higher concentration of $\mathrm{AI}$ available on the surface, while the action of super spreading, which occurs with, for example, organosilicone surfactants, can have the opposite effect, due to drastic reductions in the CA and droplet spread over surfaces (ZABKIEWICZ et al., 2007). This phenomenon can be reflected in the decrease in the relative AI concentration per unit area, thus reducing the driving force for herbicide diffusion into the leaf tissues (LIU, 2003). Additionally, high droplet dispersion tends to accelerate liquid drying, which reduces herbicide absorption.

\section{Scanning electron microscopy (SEM).}

The SEM micrographs of the adaxial surface of sourgrass before and after application of the herbicide treatments enabled qualitative analysis of the leaf surface characteristics of sourgrass and the interactions between the glyphosate formulations and adjuvants when in contact with the cuticular barrier. The epicuticular microstructures of the control treatment appear spongy, reflecting the presence of three-dimensional wax crystals (BARTHLLOTT et al., 2017), and a compact waxy layer covers almost the entire leaf surface (Figure 1, A-B). This layer is probably mainly responsible for the marked hydrorepellency of the surface to aqueous solutions, as indicated by the CA measurements (Table 2).

The stomatal densities found on the adaxial and abaxial surfaces of the sourgrass leaves were approximately 22 and $148 \mathrm{~mm}^{-2}$ stomata, respectively indicating that this species is amphistomatic; however, stomata are present in smaller numbers on the adaxial surface than on the abaxial surface. Compared to other weed species, such as Conyza bonariensis, Ipomoea cairica, and Galinsoga parviflora, sourgrass has fewer of these structures at the adaxial surface (PROCÓPIO et al., 2003). In this case, one of the main functions of spray adjuvants is to aid in overcoming or minimizing the effect of leaf waxes and the cuticular barrier (ZABKIEWICZ, 2007).

After application of the herbicide treatments, symptoms ranging from disruption of the original epicuticular wax structure to complete removal of the leaf epicuticular wax where droplets were deposited were observed, allowing visualization of the external appearance of the epidermal cells (Figures 1, C - L). These effects were more evident when the formulations were combined with the adjuvants MSO, MO and EAE. On the other hand, the adjuvant PAE had effects similar to those of the formulations alone or milder than those caused only by the formulations (Figure 1, D and I). Regarding to the leaf microstructures of corn and wheat plants application of the insecticide chlorantraniliprole, with and without different adjuvants caused rupture of the epicuticular wax (MELO et al., 2015). The addition of a vegetable oil-based adjuvant in that study was able to provide twice the penetration compared to that with the insecticide alone.

Thus, the magnitude of the visual symptoms resulting from application of the MO, EAE and MSO adjuvants found in this study is likely related to the higher affinity of the molecules of these adjuvants to the epicuticular wax present on the leaf surface of sourgrass, resulting in loss of resistance in the anatomical structures and greater exposure of the epidermal cells to herbicide penetration.

\section{Glyphosate uptake, shikimic acid accumulation and sourgrass control}

After adhesion and spreading the AI on the leaf surface, the uptake process and the interaction 


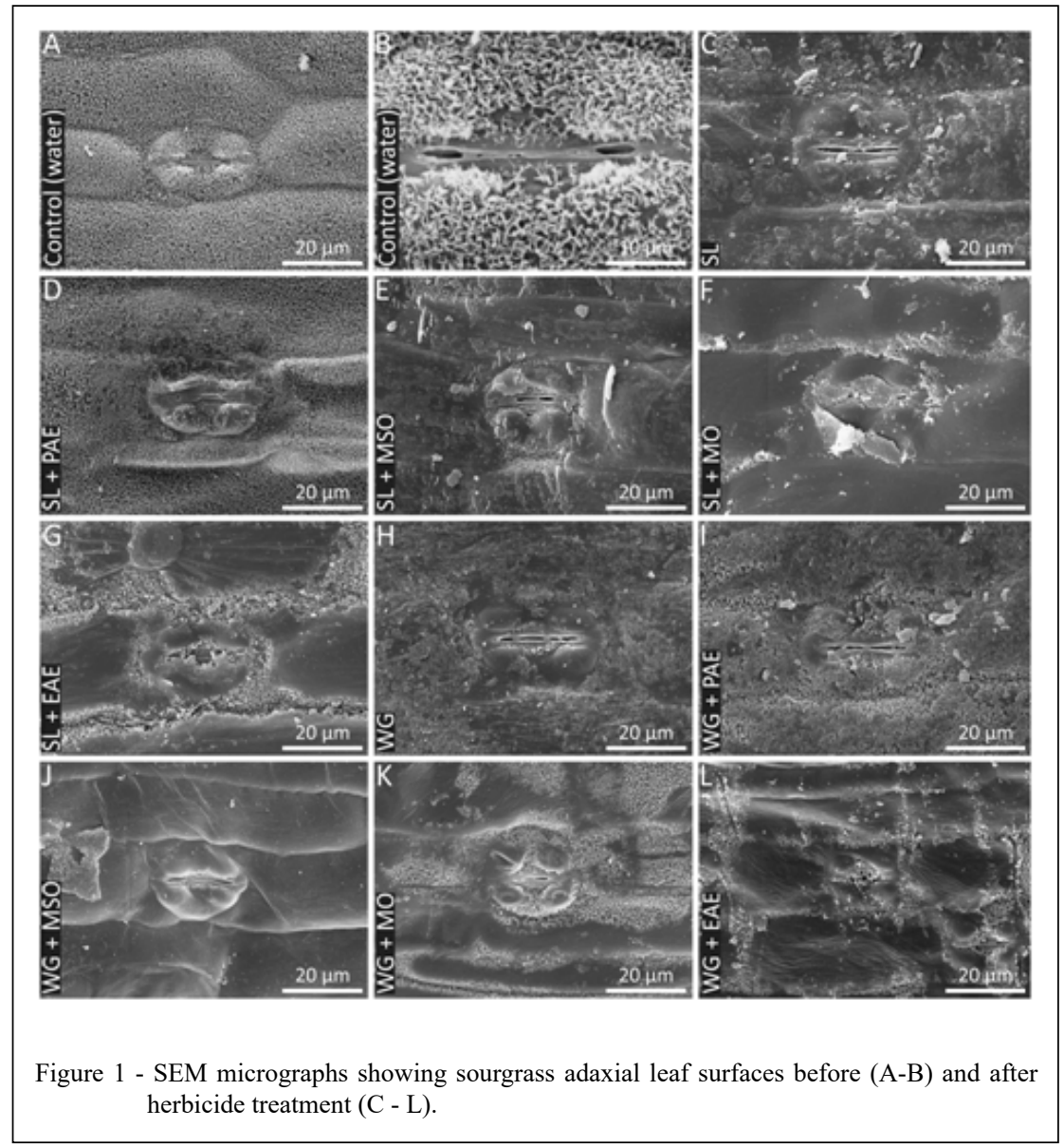

between herbicide molecules with and enzymes begin. Cuticular waxes act as a potential barrier to the absorption of organic and inorganic solutes. The mean uptake of the treatments and their respective glyphosate metabolism by sourgrass, represented by the shikimic acid accumulated in the superior tissues of the plant $24 \mathrm{HAA}$, are shown in table 3 . Additionally, the percentage of dry matter reduction at $21 \mathrm{DAA}$ is also shown in the same table.

Notably, differences $(\mathrm{P}<0.01)$ between the formulations and the adjuvants, and interactions between these factors were found, for the uptake variable, demonstrating that the effect of the formulations on uptake in sourgrass plants depends on the adjuvant added to the mix. For the shikimate variable, only the means of the adjuvants differed $(\mathrm{P}<0.01)$, while no differences $(\mathrm{P}>0.01)$ in dry matter were observed between the treatments. The magnitude of the $\mathrm{F}$ values of the adjuvant factor for the uptake and shikimate variables was higher than that found for the formulation factor, indicating that the components present in the adjuvants had a greater effect on the uptake and control of sourgrass than those in the formulations.

Agrochemical penetration is considerably affected by the solubility of the cuticle, which is indicated by the octanol/water (Log Ko/w) and cuticle/ water $(\log \mathrm{Kc} / \mathrm{w})$ partition coefficients. The uptake of hydrophilic solutes $(\log \mathrm{Ko} / \mathrm{w}<1)$ can be improved with greater hydration of the cuticle, whereas the penetration of apolar solutes with low solubility $(\log \mathrm{Ko} / \mathrm{w}>1)$ is favored by factors that modify the resistance of waxes to penetration, for example, by reducing their crystallinity (SCHEIBER \& SHÖNHERR, 2009).

The use of additives together with the AI facilitates its penetration and improves its efficacy for various reasons, such as CA reduction and, increased wettability and spreading, resulting in greater penetration through the hydrophilic pathways of this membrane (BAUR \& APONTE, 2014). Another function would is direct action on cuticular resistance to substance penetration, as shown in figure 1 .

Ciência Rural, v.52, n.8, 2022. 
Table 3 - The average glyphosate uptake, accumulated shikimic acid and sourgrass dry matter content reduction resulting from the application of different herbicide solutions.

\begin{tabular}{|c|c|c|c|c|c|c|}
\hline & ----------Upta & )------------- & ----------Shiki & g.g-1 & \multicolumn{2}{|c|}{----------DM Red. $(\%)^{a}$------------- } \\
\hline & \multicolumn{6}{|c|}{ 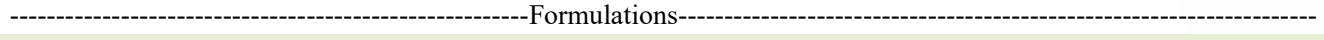 } \\
\hline Adjuvants & SL & WG & SL & WG & SL & WG \\
\hline Water & \multicolumn{2}{|c|}{ 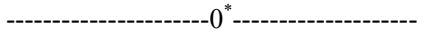 } & \multicolumn{2}{|c|}{ 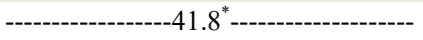 } & \multicolumn{2}{|c|}{---------------------0"---------------------- } \\
\hline Without adj. & $2.1 \mathrm{aC}$ & $2.6 \mathrm{aC}$ & $431.0 \mathrm{aC}$ & $529.3 \mathrm{aB}$ & $87.0 \mathrm{aA}$ & $79.4 \mathrm{aA}$ \\
\hline PAE & $2.5 \mathrm{aC}$ & $2.9 \mathrm{aC}$ & $523.8 \mathrm{aBC}$ & $476.8 \mathrm{aB}$ & $79.3 \mathrm{aA}$ & $88.7 \mathrm{aA}$ \\
\hline MSO & $5.0 \mathrm{aB}$ & $3.5 \mathrm{bBC}$ & $626.3 \mathrm{aAB}$ & $628.3 \mathrm{aAB}$ & $88.1 \mathrm{aA}$ & $82.8 \mathrm{aA}$ \\
\hline MO & $5.8 \mathrm{aAB}$ & $4.7 \mathrm{bAB}$ & $657.5 \mathrm{aAB}$ & $613.8 \mathrm{aAB}$ & $78.1 \mathrm{aA}$ & $78.2 \mathrm{aA}$ \\
\hline EAE & $6.5 \mathrm{aA}$ & $5.9 \mathrm{aA}$ & $744.0 \mathrm{aA}$ & $693.8 \mathrm{aA}$ & $73.5 \mathrm{aA}$ & $77.5 \mathrm{aA}$ \\
\hline $\mathrm{F}_{(\mathrm{F})} ; \mathrm{F}_{(\mathrm{A})}$ & \multicolumn{2}{|c|}{--------------4.93*'; $26.33^{*}$--------------- } & \multicolumn{2}{|c|}{--------------0.40" } & \multicolumn{2}{|c|}{-----------0.00 ${ }^{\text {ns }} ; 1.31^{\text {ns }}$} \\
\hline $\mathrm{F}_{(\mathrm{FxA})} ; \mathrm{CV}$ & \multicolumn{2}{|c|}{-------------3.07**; $; 24.7 \%$--------------- } & \multicolumn{2}{|c|}{--------------1.76 } & \multicolumn{2}{|c|}{ 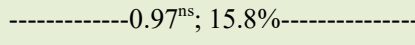 } \\
\hline
\end{tabular}

${ }^{a}$ Reduction in the dry matter content compared to treatment without herbicide application. ${ }^{\text {ns Not significant }(\mathrm{P}>0.05) ;{ }^{* *} \text { Significant }(\mathrm{P}<}$ 0.05 ) by the F test; Averages followed by the same letter, lowercase on the line and uppercase on the column for each chemical compound, do not differ by Tukey's test $(\mathrm{P}<0.05)$; "Indicates the difference in control (water) compared to other treatments, by Dunnett's test $(\mathrm{P}<0.05)$.

Comparison of the uptake between the formulations with different adjuvants shows that MSO and MO demonstrated better interactions with the SL formulation, resulting in greater uptake of the treatments within 24 HAA. Lipophilic adjuvants, when combined with SL formulations, which also have lipophilic properties, likely have a synergistic or additive effect, acting as accelerators of glyphosate absorption (SCHREIBER \& SCHÖNHERR, 2009). However, for the formulations alone or in combination with the other adjuvants, no differences $(\mathrm{P}<0.01)$ were found between the treatments for the variables under study.

Comparison of the mean values for the uptake and shikimate associated with the adjuvants in the different formulations shows that the addition of the adjuvant PAE provided results similar to those found for the treatments without adjuvants, with no improvements in the attributes related to application quality.

These results differ from those obtained by LIU (2004), who found that the addition of polyoxyethylene surfactants, especially those with high EO concentrations, yields higher levels of glyphosate uptake in wheat. Evidence indicates that glyphosate formulations already contain adjuvants with effects similar to those of the polyoxyethylene adjuvant used in this study (TSUI \& CHU, 2003), which justifies the similarity between the data for formulations used alone and in combination with this adjuvant. However, the MSO, MO, and EAE adjuvants, in this order, stood out from the other treatments because they generated increases (P
$<0.01)$ in $\mathrm{AI}(138 \%$ to $209 \%)$ and shikimic acid accumulation $(45 \%$ to $73 \%)$ relative to the values obtained with the SL formulation without adjuvants.

Regarding of the EAE adjuvant, advantages in the diffusion of 2,4-D in the cuticular membranes of barley and jasmine were observed when this herbicide was combined with different n-alkyl esters. Higher concentrations of the adjuvant in the spray solution resulted in linear increases in penetration in both species, and these effects were approximately five times higher than those observed for the combination with ethoxylated alcohols (SIMANOVA et al., 2005). These results can partially explain the data found in the present work, where the addition of an alkyl ester (EAE) to glyphosate formulations conferred greater herbicide absorption and shikimate accumulation, compared to treatments without adjuvants and those with a polyoxyethylene adjuvant.

These results may be attributed to greater damage to the epicuticular structures induced by oilbased adjuvants, reducing the permeability of the cuticular membrane to the herbicide solutions and thus increasing glyphosate penetration at the sites where the AI was deposited. Despite the differences found for uptake and metabolic action between treatments, the results for the percentage of dry matter reduction were similar (Table 3).

Significant differences $(\mathrm{P}<0.01)$ between the formulations and adjuvants and interactions between the factors were observed at 14 DAA when analyzing the visual control symptoms (Table 4). These observations were similar to those at 21 DAA 
Table 4 - The average data for visual symptoms control at 7, 14 and 21 days after applying (DAA) different spray solutions with glyphosate on sourgrass.

\begin{tabular}{|c|c|c|c|c|c|c|}
\hline \multirow[t]{3}{*}{ Adjuvants } & \multicolumn{6}{|c|}{ 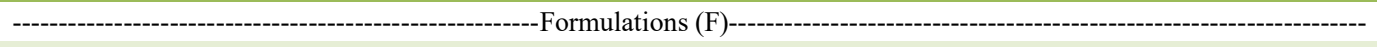 } \\
\hline & \multicolumn{2}{|c|}{-----------------7 DAA-------------- } & \multicolumn{2}{|c|}{ 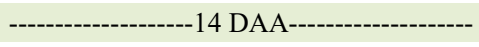 } & \multicolumn{2}{|c|}{ 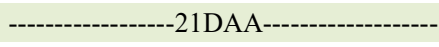 } \\
\hline & SL & WG & SL & WG & SL & WG \\
\hline Without adj. & $54.0 \mathrm{aA}$ & $48.8 \mathrm{aA}$ & $88.6 \mathrm{aAB}$ & $84.0 \mathrm{aB}$ & $99.0 \mathrm{aA}$ & $98.8 \mathrm{aA}$ \\
\hline PAE & $50.6 \mathrm{aA}$ & $54.8 \mathrm{aA}$ & $81.4 \mathrm{bB}$ & $95.8 \mathrm{aAB}$ & $94.8 \mathrm{bB}$ & $99.8 \mathrm{aA}$ \\
\hline MSO & $51.0 \mathrm{aA}$ & $47.8 \mathrm{aA}$ & $82.8 \mathrm{aB}$ & $86.8 \mathrm{aAB}$ & $99.2 \mathrm{aA}$ & $98.6 \mathrm{aA}$ \\
\hline MO & $47.4 \mathrm{aA}$ & $46.8 \mathrm{aA}$ & $98.0 \mathrm{aA}$ & $94.4 \mathrm{aAB}$ & $100.0 \mathrm{aA}$ & $98.6 \mathrm{aA}$ \\
\hline EAE & $48.0 \mathrm{aA}$ & $46.4 \mathrm{aA}$ & $92.4 \mathrm{aAB}$ & $98.0 \mathrm{aA}$ & $100.0 \mathrm{aA}$ & $99.6 \mathrm{aA}$ \\
\hline Water & \multicolumn{2}{|c|}{ 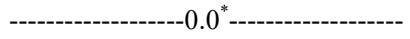 } & \multicolumn{2}{|c|}{ 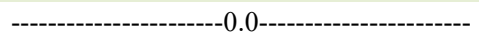 } & \multicolumn{2}{|c|}{---------------------0,0--------------------- } \\
\hline $\mathrm{F}_{(\mathrm{F})} ; \mathrm{F}_{(\mathrm{A})}$ & \multicolumn{2}{|c|}{---------- $0.78^{\text {ns, }} ; 2.38^{\text {ns }}$} & \multicolumn{2}{|c|}{ 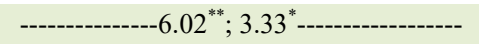 } & \multicolumn{2}{|c|}{-------------1 $1.96^{\text {ns; }} ; 5.96^{* *}-------------$} \\
\hline $\mathrm{F}_{(\mathrm{FxA})} ; \mathrm{CV}$ & \multicolumn{2}{|c|}{ 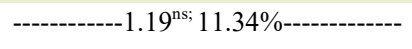 } & \multicolumn{2}{|c|}{ - } & \multicolumn{2}{|c|}{ 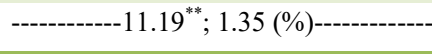 } \\
\hline
\end{tabular}

${ }^{n s}$ Not significant $(\mathrm{P}>0.05) ;{ }^{* *}$ Significant $(\mathrm{P}<0.05)$ by the $\mathrm{F}$ test; Averages followed by the same letter, lowercase on the line and uppercase on the column for each evaluation time, do not differ by Tukey's test $(\mathrm{P}<0.05)$; ${ }^{*}$ Indicates a difference in the control (water) compared to other treatments by Dunnett's test $(\mathrm{P}<0.05)$.

except for the formulations, which did not show significant differences at in this evaluation time.

When comparing the formulations, a slight advantage, at 14 and 21 DAA, was verified among the mixtures that containing the PAE adjuvant: better control was achieved when this adjuvant was added to the WG based formulation, indicating a greater interaction of this polyoxyethylene with the lipophilic formulation. For the other mixtures, no significant differences were found

Among the adjuvants, MO optimized the control conferred by the spray solutions containing the SL formulation and therefore, stood out from the other treatments, with a significant difference from spray solutions containing the PAE and MSO adjuvants. On the other hand, the EAE adjuvant stood out in the mixtures containing the WG formulation, differing significantly from the treatment without adjuvant, suggesting faster effect these mixtures on sourgrass control.

Despite the significant differences in visual control obtained at 14 and 21 DAA, the means of all treatments exceeded a control level of $80 \%$, which was considered satisfactory for herbicide applications. Notably, in critical field control scenarios, such as the occurrence of rain after application, plants at advanced growth stages, or even application in fields with the presence of resistant sourgrass plants, the treatments may show greater differences in effectiveness, with advantages of mixtures containing oil-based adjuvants.

\section{Correlation between variables}

A strong inverse correlation $(\mathrm{P}<0.05)$ was found between the $\mathrm{CA}$ measurements on the natural surface and uptake $\left(\mathrm{R}^{2}=-0.896\right)$. An inverse correlation also found between CAs and accumulated shikimic acid $\left(\mathrm{R}^{2}=-0.878\right)$ and a strong direct correlation was observed between the uptake and accumulated shikimic acid data $\left(\mathrm{R}^{2}=0.858\right)$, as shown in figure 2.

In general, these results show that increased wettability (a reduced CA) promoted by the formulations and adjuvants resulted in increased glyphosate uptake (Figure 2, A) and consequent action on the metabolism of sourgrass $D$. insularis (Figure 2, B). The increased in glyphosate uptake promoted effective obstruction of the metabolism of sourgrass (Figure 2, C), causing greater accumulation of shikimic acid over a $24 \mathrm{~h}$ period. These data may be directly related to the increase not only in the herbicide amount absorbed but also in the rate of uptake of the AI and the action on plant metabolism.

In summary, the study showed that the formulations have a small impact on the analyzed variables, while the adjuvants are the most important components for increasing the AI's action for sourgrass control. The interactions observed between the analyzed variables showed that oil-based adjuvants, such as MSO, MO and EAE, combine better with the lipophilic formulation. Furthermore, hydrophilic adjuvant has some advantages when mixed with a water-soluble formulation. 

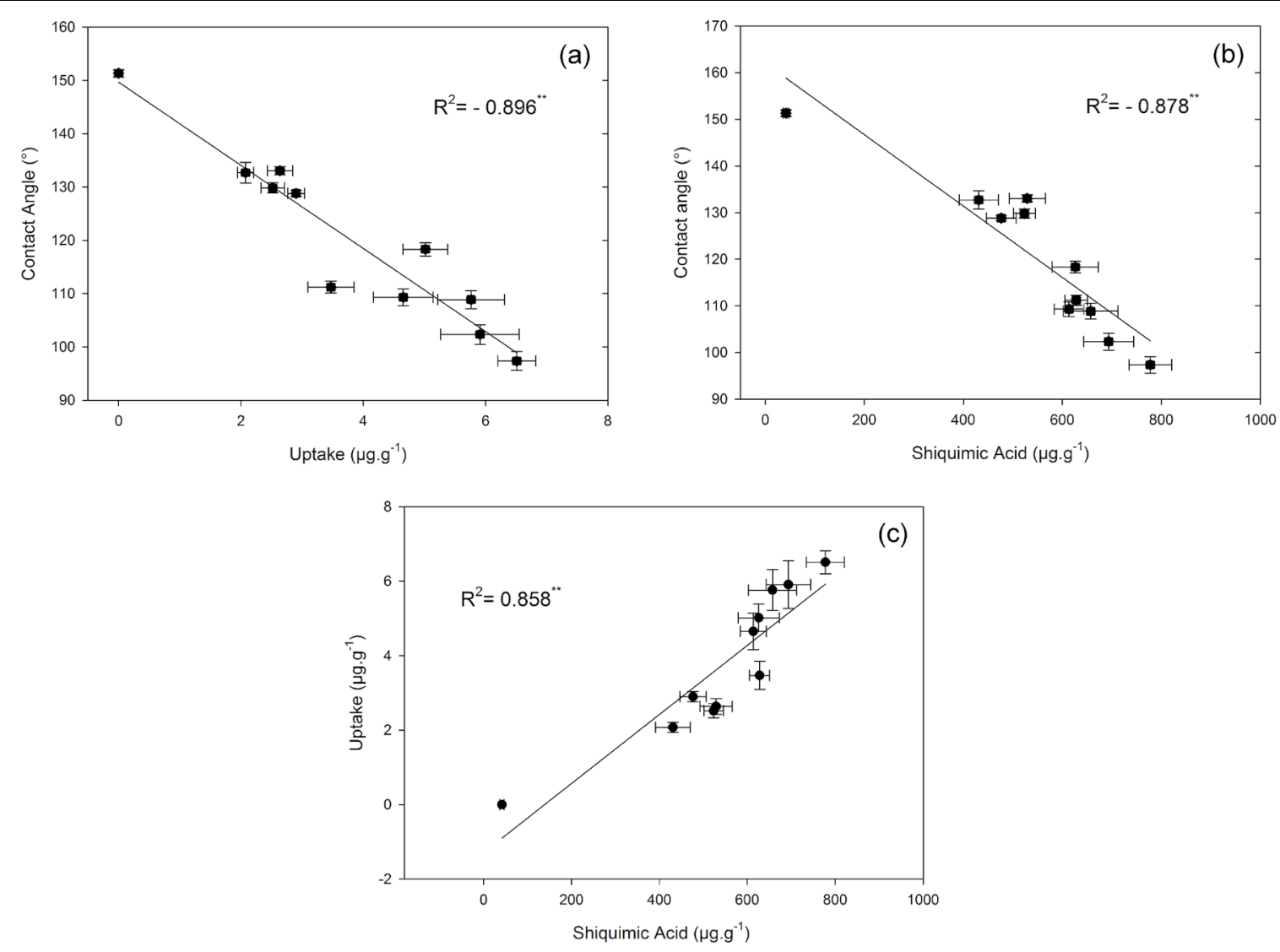

Figure 2 - Correlations between CA and uptake (a); CA and shikimic acid (b); and uptake and accumulated shikimic acid (c). The points correspond to the average treatment values, and the vertical and horizontal bars are the average standard errors.

Sourgrass control can be optimized through the addition of oily adjuvants, especially MO and EAE, with advantages related to wettability and dispersion of droplets deposited on the target, thus preventing losses due to run-off and salt crystallization. Additionally, these adjuvants cause greater damage to the leaf microstructure, facilitating absorption and increasing metabolic obstruction. Finally, these factors must be considered in field recommendations, aiming to optimize the use of glyphosate to control this grass.

\section{CONCLUSION}

Glyphosate formulations interact with adjuvants to increase herbicide performance in sourgrass control. Adjuvants are the spray solution components with the greatest impact on the analyzed variables. Among the adjuvants evaluated MO and,
EAE that stood out, promoting greater wettability and activity on the cuticular surface, with greater impacts on foliar absorption and metabolism. Combining glyphosate formulations with these adjuvants is potentially more effective and ensures satisfactory sourgrass, control, especially under unfavorable conditions in the field.

\section{ACKNOWLEDGEMENTS}

This study was supported by Conselho Nacional de Desenvolvimento Científico e Tecnológico (CNPq) (grant $\mathrm{N}^{\mathbf{0}}$. 159038/2013-8), and Coordenação de Aperfeiçoamento de Pessoal de Nível Superior (CAPES) - Finance code 001.

\section{DECLARATION OF CONFLICT OF INTEREST}

The authors declare no conflict of interest. The founding sponsors had no role in the design of the study; in the 
collection, analysis, or interpretation of data; in the writing of the manuscript, or in the decision to publish the results.

\section{AUTHORS' CONTRIBUTIONS}

JDC, CGR and CAC conceived and designed experiments. JDC and SAS performed the experiments and carried out the lab analyses. JDC supervised and coordinated the plants experiments and provided clinical data. JDC performed statistical analyses of experimental data. JDC, CGR and SAS prepared the draft of the manuscript. All authors critically revised the manuscript and approved of the final version.

\section{REFERENCES}

APPAH, S. et al. Analysis of potential impaction and phytotoxicity of surfactant-plant surface interaction in pesticide application. Crop Protection. v.127, e104961, 2020. Available from: <http:// dx.doi.org/10.1016/j.cropro.2019.104961>. Accessed: Mar. 20, 2020. Epub 16-Sep-2019. doi: 10.1016/j.cropro.2019.104961.

ARAND, K. et al. The mode of action of adjuvants - relevance of physicochemical properties for effects on the foliar application, cuticular permeability, and greenhouse performance of pinoxaden. Journal of Agricultural and Food Chemistry, v.66, p.5770-5777, 2018. Available from: $<$ https://doi.org/10.1021/acs.jafc.8b01102>. Accessed: Oct. 02, 2020. doi: 10.1021/acs.jafc.8b01102.

ASOCIACION LATINOAMERICANA DE MALEZAS (ALAM). Recomendaciones sobre unificación de los sistemas de evaluación em ensayos de control de malezas, v.19. p.35-38, 1974.

ASMUS, E. et al. Water sorption isotherms of surfactants: a tool to evaluate humectancy. Journal of Agricultural and Food Chemistry, v.64, p.5310-5316, 2016. Available from: <https:// doi.org/10.1021/acs.jafc.6b01378>. Accessed: Oct. 05, 2020 doi: 10.1021/acs.jafc.6b01378.

BAUR, P.; APONTE, J. Co-penetration of actives and adjuvants and its significance for the matched pair liaison. In: MYUNG, K. et al. Retention, uptake, and translocation of agrochemicals in plants. Washington: American Chemical Society, 2014. Chap 2, e9780841229730. Available from: <https://pubs.acs.org/doi/ abs/10.1021/bk-2014-1171.ch002>. Accessed: Aug. 08, 2020 Epub 15-Oct-2014. doi: 10.1021/bk-2014-1171.ch002.

BARTHLOTT, W. et al. Superhydrophobic hierarchically structured surfaces in biology: evolution, structural principles and biomimetic applications. Philosophical Transactions of The Royal Society A Mathematical Physical and Engineering Sciences. v.374, e20160191, 2017. Available from: <https://royalsocietypublishing. org/doi/pdf/10.1098/rsta.2016.0191>. Accessed: Aug. 10, 2020. Epub 06-Aug-2016. doi: 10.1098/rsta.2016.0191.

CAVALIERI, J. D. et al. Spraying systems and traveling speed in the deposit and spectrum of droplets in cotton plant. Engenharia Agrícola. v.6, n.6, p.1042-1052, 2015. Available from: <http://dx.doi.org/10.1590/1809-4430-Eng. Agric.v35n6p1042-1052/2015>. Accessed: Jun. 04, 2020. doi: 10.1590/1809-4430-Eng.Agric.v35n6p1042-1052/2015.

CARVALHO, L. B. et al. 2012. Pool of resistance mechanisms to glyphosate in Digitaria insularis. Journal of Agricultural and Food Chemistry. v.60, n.2, p.615-622, 2012. Available from: <https://doi.org/10.1021/jf204089d>. Accessed: Feb. 15, 2020. doi: $10.1021 /$ jf204089d.

COSTA, G. A. et al. Efficiency of glyphosate and carfentrazoneethyl in the control of Macroptilium atropurpureum (DC.) Urb. under different light intensities. South African Journal of Botany. v.131, p.302-309, 2020. Available from: <https://doi. org/10.1016/j.sajb.2020.02.028>. Accessed: Jan. 12, 2020. doi: $10.1016 /$ j.sajb.2020.02.028

DUKE, S. O.; POWLES, S. B. Glyphosate: a once-in-a-century herbicide. Pest Management Science, v.64, n.6, p.319-325, 2008. Available from: <https://doi.org/10.1002/ps.1518>. Accessed: Mar. 02, 2020. doi: 10.1002/ps.1518.

GEMELLI, A., et al. Aspectos da biologia de Digitaria insularis resistente ao glyphosate e implicações para o seu controle. Revista Brasileira de Herbicidas. v.11, n.2, p.231-240, 2012. Available from: $\quad<$ https://doi.org/10.7824/rbh.v11i2.186portuguespdf $>$. Accessed: Oct. 03, 2020. doi: 10.7824/rbh.v11i2.186.

GIMENES, M. J. et al. Dispersion and evaporation of droplets amended with adjuvants on soybeans. Crop Protection, v.44, p.84-90, 2013. Available from: <https://doi.org/10.1016/j. cropro.2012.10.022>. Accessed: Feb. 18, 2020. doi: 10.1016/j. cropro.2012.10.022.

GOMES, G. L. C. et al. Extraction and simultaneous determination of glyphosate, AMPA and compounds of the shikimic acid pathway in plants. Planta Daninha, v.33, p.295-304, 2015. Available from: $<$ https://doi.org/10.1590/0100-83582015000200015>. Accessed: Aug. 03, 2020. doi: 10.1590/0100-83582015000200015.

LOPEZ OVEJERO, R. F. et al. Frequency and dispersal of glyphosate-resistant sourgrass (Digitaria insularis) populations across Brazilian agricultural production areas. Weed Science, v.65, n.2, p.285-294, 2017. Available from: <https://doi.org/10.1017/ wsc.2016.31>. Accessed: Aug. 16, 2020. doi: 10.1017/wsc.2016.31.

LIU, Z. Q. Characterization of glyphosate uptake into grass species. Australian Journal of Agricultural Research, v.54, n.9, p.877884, 2003. Available from: <https://doi.org/10.1071/AR03063>. Accessed: Aug. 03, 2020. doi: 10.1071/AR03063.

LIU, Z. Q. Effects of surfactants on foliar uptake of herbicides - a complex scenario. Colloids And Surfaces B: Biointerfaces, v.35, p.149-153, 2004. Available from: <https://doi.org/10.1016/j. colsurfb.2004.02.016>. Accessed: Nov. 20, 2019. doi: 10.1016/j. colsurfb.2004.02.016.

KARNOVSKY, M. J. A. Formaldehyde-glutaraldehyde fixative of high osmolarity for use in electron microscopy. Journal Histochemistry and Citochemistry, v.27, p.137- 138, 1965. Available from: $<$ https://doi.org/10.1016/j.colsurfb.2004.02.016>. Accessed: Mar. 13, 2020. doi: 10.1016/j.colsurfb.2004.02.016.

KOCH, K.; BARTHLOTT, W. Superhydrophobic and superhydrophilic plant surfaces: an inspiration for biomimetic materials. Philosophical Transactions of the Real Society A, v.367, p.1487-1509, 2009. Avaliable from: <https://doi. org/10.1098/rsta.2009.0022>. Accessed: Jul. 10, 2020. doi: 10.1098/rsta.2009.0022.

OLIVEIRA, R. B. et al. Effect of droplet size and leaf surface on retention of 2,4-D formulations. Crop Protection, v.119, p.97-101, 2019. Available from: <https://doi.org/10.1016/j. 
cropro.2019.01.015>. Accessed: May, 01, 2020. doi: 10.1016/j. cropro.2019.01.015.

MASSINON, M. et al. Study of retention variability on an early growth stage herbaceous plant using a 3D virtual spraying model. Crop Protection, v.78, p.63-71, 2015. Available from: $<$ https:// doi.org/10.1016/j.cropro.2015.08.018>. Accessed: Dec. 21, 2019. doi: $10.1016 /$ j.cropro.2015.08.018

MASSINON, M. et al. Spray droplet impaction outcomes for different plant species and spray formulations. Crop Protection, v.99, p.65-75, 2017. Available from: <https://doi.org/10.1016/j. cropro.2017.05.003>. Accessed: Dec. 21, 2019. doi: 10.1016/j. cropro.2017.05.003.

MELO, A. A. et al. Impact of tank-mix adjuvants on deposit formation, cuticular penetration and rain-induced removal of chlorantraniliprole. Crop Protection. v.78, p.253-262, 2015. Available from: <https://doi.org/10.1016/j.cropro.2015.09.021>. Accessed: Feb. 02, 2020. doi: 10.1016/j.cropro.2015.09.021.

NAIRN, J. J. et al. Effect of solution and leaf surface polarity on droplet spread area and contact angle. Pest Management Science, v.72, n.3, p.551-557, 2015. Available from: $<$ https://doi. org/10.1002/ps.4022>. Accessed: Dec. 25, 2019. doi: 10.1002/ ps.4022.

PALMA-BAUTISTA, C. et al. Effect of adjuvant on glyphosate effectiveness, retention, absorption and translocation in Lolium rigidum and Conyza Canadensis. Plants (Basel). v.9, n.3, e7154921, 2020. Available from: <https://doi.org/10.3390 plants9030297>. Accessed: Aug. 03, 2020. Epub 01-Mar-2020. doi: $10.3390 /$ plants 9030297 .

PROCÓPIO, S. O. et al . Estudos anatômicos de folhas de espécies de plantas daninhas de grande ocorrência no Brasil: III - Galinsoga parviflora, Crotalaria incana, Conyza bonariensis e Ipomoea cairica. Planta Daninha, Viçosa, v.21, n.1, p.1-9, 2003. Available from: $<$ http://www.scielo.br/scielo.php?script $=$ sci arttext\&pid=S0 $10083582003000100001 \& \operatorname{lng}=$ en $\& n r m=$ iso $>$. Accessed: Dec. 11 , 2020. doi: 10.1590/S0100-83582003000100001.

RODRIGUES, B. N.; ALMEIDA, F. S. Guia de Herbicidas. Londrina, 7ed. 2018. 764p.

SANTOS, R. T. S. et al. Does the use of adjuvants alter surface tension and contact angle of herbicide spray droplets on leaves of Sida spp.? Planta Daninha, v.37, e019185603, 2019. Available from: $\quad<$ https://doi.org/10.1590/s0100-83582019370100082>. Accessed: Mar. 28, 2019. Epub 30-Sep-2019 doi: 10.1590/S010083582019370100082 .
SILVEIRA, H. M. et al. Glyphosate efficacy on sourgrass biotypes with suspected resistance collected in GR-crop fields. Acta Scientiarum. Agronomy. v.40, e35120, 2018. Available from: $<$ https://doi.org/10.4025/actasciagron.v40i1.35120>. Accessed: Feb. 28, 2020. Epub 05-Fev-2018. doi: 10.4025/actasciagron. v40i1.35120.

SIMANOVA, E. et al. Sorption in reconstituted waxes of homologous series of alcohol ethoxylates and n-alkyl esters and their effects on the mobility of 2,4-dichlorophenoxybutyric acid. Pest Management Science, v.61, p.383-389, 2005. Available from: <https://doi.org/10.1002/ps.979>. Accessed: Feb. 23, 2020. doi: $10.1002 /$ ps. 979 .

SHI, T. et al. Accelerators increase permeability of cuticles for the lipophilic solutes metribuzin and iprovalicarb but not for hydrophilic methyl glucose. Journal of Agricultural and Food Chemistry, v. 53 , n.7, p.2609-2615, 2005. Available from: <https://doi.org/10.1021/ jf048242w>. Accessed: Sep. 12, 2020. doi: 10.1021/jf048242w.

SCHREIBER L.; SCHÖNHERR J. Penetration of ionic solutes. No: Water and solute permeability of plant cuticles. 3.ed. Heidelberg: Springer, 2009. Chap. 5. p.125-144.

SCHRÜBBERS, L. C. et al. Glyphosate spray drift in Coffea arabica - Sensitivity of coffee plants and possible use of shikimic acid as a biomarker for glyphosate exposure. Pesticide Biochemistry and Physiology, v.115, n.1, p.15-22, 2014. Available from: <https:// doi.org/10.1016/ j.pestbp.2014.08.003>. Accessed: Feb. 28, 2020. doi: 10.1016 / j.pestbp.2014.08.003

SOCIEDADE BRASILEIRA DA CIÊNCIA DAS PLANTAS DANINHAS - SBCPD. Procedimentos para instalação, avaliação e análise de experimentos com herbicidas. Londrina: 1995. 42p.

STOCK, D. et al. Surfactant-enhanced foliar uptake of some organic compounds: interactions with two model polyoxyethylene aliphatic alcohols. Pesticide Science, v.34, p.233-242, 1992. Available form: <https://doi.org/10.1002/ps.2780340308>. Accessed: Sep. 13, 2020. doi: 10.1002/ps.2780340308.

TSUI, M. T. K.; CHU, L. M. Aquatic toxicity of glyphosate-based formulations: comparison between different organisms and the effects of environmental factors. Chemosphere, v.52, p.1189-1197, 2003. Available from: <https://doi.org/10.1016/S0045-6535(03)00306-0> . Accessed: Aug. 22, 2020. doi: 10.1016/S0045-6535(03)00306-0.

ZABKIEWICZ, J. A. Spray formulation efficacy-holistic and futuristic perspectives. Crop Protection. v.26, n.3, p.312-319, 2007. Available from: <https://doi.org/10.1016/j.cropro.2005.08.019>. Accessed: Aug. 13, 2020. doi: 10.1016/j.cropro.2005.08.019. 